\title{
超急速短時間加熱焼入れしたフェライト地の 球状黒鉛鋳鉄の疲労強度*
}

\author{
三 阪 佳 孝 $^{1} \quad$ 川嵩 一 博1 $\quad$ 小茂鳥 $\quad$ 潤 $^{2} \quad$ 清水真佐男 2 \\ 1高周波熱錬株式会社 \\ 2 慶應義塾大学理工学部
}

J. Japan Inst. Metals, Vol. 69, No. 12 (2005), pp. 1057-1063

(C) 2005 The Japan Institute of Metals

\section{Fatigue Strength of Ferritic Ductile Cast Iron Hardened by Super Rapid Induction Heating and Quenching}

Yoshitaka Misaka ${ }^{1}$, Kazuhiro Kawasaki ${ }^{1}$, Jun Komotori² and Masao Shimizu²

${ }^{1}$ NETUREN Co., Ltd., Hiratsuka 254-0013

${ }^{2}$ Department of Mechanical Engineering, Keio University, Yokohama 223-8522

To clarify the effects of Super Rapid Induction Heating and Quenching (SRIHQ) on fatigue properties of Ferritic Ductile Cast Iron (FDI), rotational bending fatigue tests were carried out on specimens treated with four types of heating cycle. Results showed that; (i) the SRIHQ process generated a thin dark gray area around the graphite. This dark area was composed of a martensite structure (ringed martensite). (ii) The ringed martensite generated a compressive residual stress field at the surface hardened layer. Two types of compressive residual stress generative mechanisms were observed. One was a microscopic residual stress generative process due to the formation of ringed martensite and the other was a macroscopic residual stress generative process due to the expansion of the surface hardened layer. (iii) The fatigue strength of SRIHQ treated FDI specimen was higher than that of the untreated one. This was because the compressive residual stress field generated by the ringed martensite suppressed initiation and propagation of fatigue cracks.

(Received September 15, 2005; Accepted October 7, 2005)

Keywords: rotational bending fatigue, fracture mechanism, super-rapid induction heating and quenching, ferritic ductile cast iron

\section{1. 緒言}

球状黒鉛鋳鉄はニアネットシェイプ化が容易であるという 特徵に加えて優れた切削加工性を示し, 成形加工工数の削減 が図れるため, 機械構造部材として幅広く使用されている. しかし，溶製材である鉄鋼材料に比べて，高強度材として使 用されることは少ない。この原因は鋳鉄内の黒鉛や巣など が, 欠陥, 切欠として作用するためで, 一般には, 高い疲労 強度が要求される部材への適用は困難とされている. そのた めに, 鋳物組成, 鋳造方法, 熱処理方法などについて疲労強 度の改善・安定策が検討されている1,2).

近年, 大型の高周波誘導加熱発振器の高出力を $1 / 10000$ 秒の超短時間で高精度制御する技術が実用化され，これを用 いることにより，0.5 s 以内の超急速短時間加熱焼入れ (SRIHQ: Super Rapid Induction Heating and Quenching)が 可能となり，硬化層深さを極めて高精度にコントロールでき ることにより, 高硬さ, 高圧縮残留応力, 低変形を有する歯 車が創生できることが示されており ${ }^{3-6)}$, この SRIHQを種 々の部材へ適用桩大するためには, その高強度化機構を明ら

\footnotetext{
* Mater. Trans. 45(2004) 2930-2935 に掲載
}

かにすることが重要な課題となっている.

著者らは, 溶製材である $\mathrm{S} 45 \mathrm{C}$ 鋼に, 異なる硬化層深さで SRIHQ を施し, 回転曲げ度労特性を評価した結果, SRIHQ を施した硬化層には極めて高い圧縮残留応力が存在し, これ により, 疲労強度特性の向上が図れることを明らかにしてい $ろ^{4)}$. 特に, ノッチ底のような応力集中箇所を有した試験片 においては, 極めて高い疲労強度が創生され, SRIHQ が歯 車のようないわば切欠きを有した部材の疲労強度改善に有効 であることを明らかにしている4).

そこで, 本研究では SRIHQ プロセスによるフェライト地 の球状黒鉛鋳鉄 FDI(Ferritic Ductile Cast Iron)の疲労強度 向上と信頼性向上の可能性を明らかにすることを目的に実験 を行った。

\section{2. 実 験 方 法}

供試材には $400 \mathrm{MPa}$ の引張強度を有する FDI(FCD400) を用いた. Table 1 に化学成分, 機械的性質を示す。なお, 鋳造欠陥のバラツキをできるだけ少なくするために, 鋳込ま れた鋳型の下部から, 各ブロックより一本ずつ試験片を採取 した.そして Fig. 1 に示す試験片形状に加工した。

次に, Fig. 2 に示す熱処理サイクルで加熱温度を 1248 K 
Table 1 Chemical compositions and mechanical properties of the alloy used

\begin{tabular}{|c|c|c|c|c|c|c|c|}
\hline & & & & & & \multicolumn{2}{|c|}{ (mass $\%)$} \\
\hline & $\mathrm{C}$ & $\mathrm{Si}$ & $\mathrm{Mn}$ & $\mathrm{P}$ & S & $\mathrm{Mg}$ & $\mathrm{Cu}$ \\
\hline FCD 400 & 3.73 & 2.24 & 0.46 & 0.02 & 0.007 & 0.44 & 0.02 \\
\hline & \multicolumn{2}{|c|}{ T.S $(\mathrm{MPa})$} & & \multicolumn{2}{|c|}{ Y.S (MPa) } & \multicolumn{2}{|c|}{ El. $(\%)$} \\
\hline FCD 400 & \multicolumn{2}{|c|}{422} & & \multicolumn{2}{|c|}{268} & \multicolumn{2}{|c|}{23.7} \\
\hline
\end{tabular}

T.S: Tensile strength Y.S: Yield strength El.: Elongation

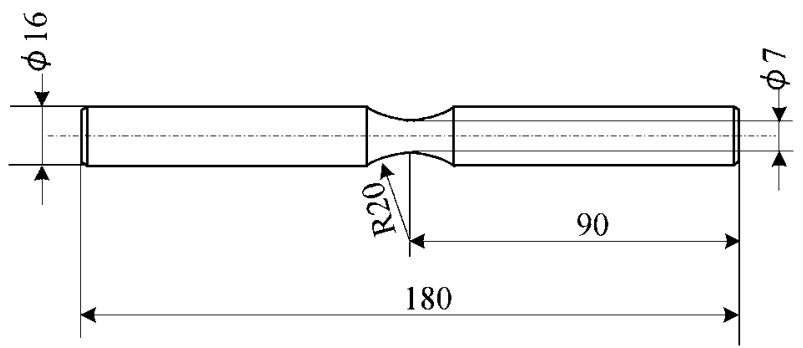

Fig. 1 Specimen configuration.
で一定として加熱時間を $0.13 \sim 7.3 \mathrm{~s}$ とした SRIHQ を施し た。加熱時間の違いにより，それぞれ $\mathrm{A}(0.13), \mathrm{B}(0.37), \mathrm{C}$ (1.15)，D(7.3)シリーズとした. 各試験片について, 試験片 $\mathrm{R}$ 部の軸方向 $(\mathrm{L})$ 断面の深さ方向にマイクロビッカース硬さ (荷重 $2.94 \mathrm{~N}$ ) 分布を測定した. また, 微小部 X 線応力測定

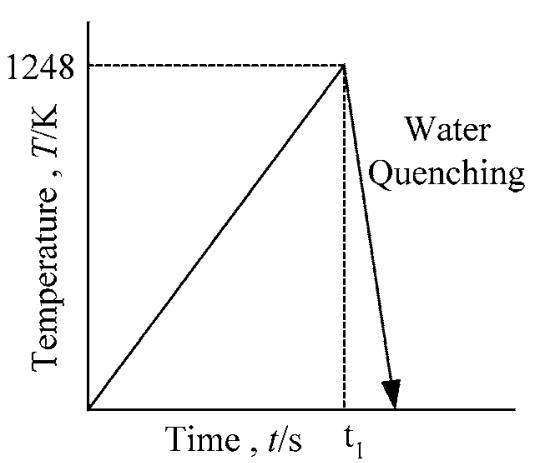

\begin{tabular}{|c|c|}
\hline Series & $\mathrm{t}_{1}(\mathrm{~s})$ \\
\hline $\mathrm{A}$ & 0.13 \\
\hline $\mathrm{B}$ & 0.37 \\
\hline $\mathrm{C}$ & 1.15 \\
\hline $\mathrm{D}$ & 7.3 \\
\hline
\end{tabular}

Fig. 2 Heating cycle for Super-Rapid Induction Heating and Quenching.

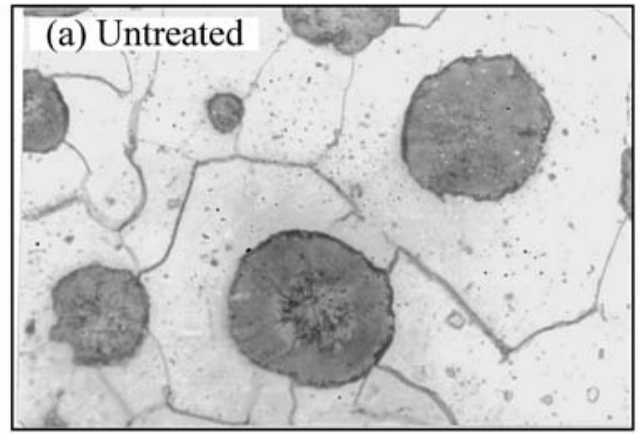

$\mathbf{5 0} \mu \mathbf{m}$
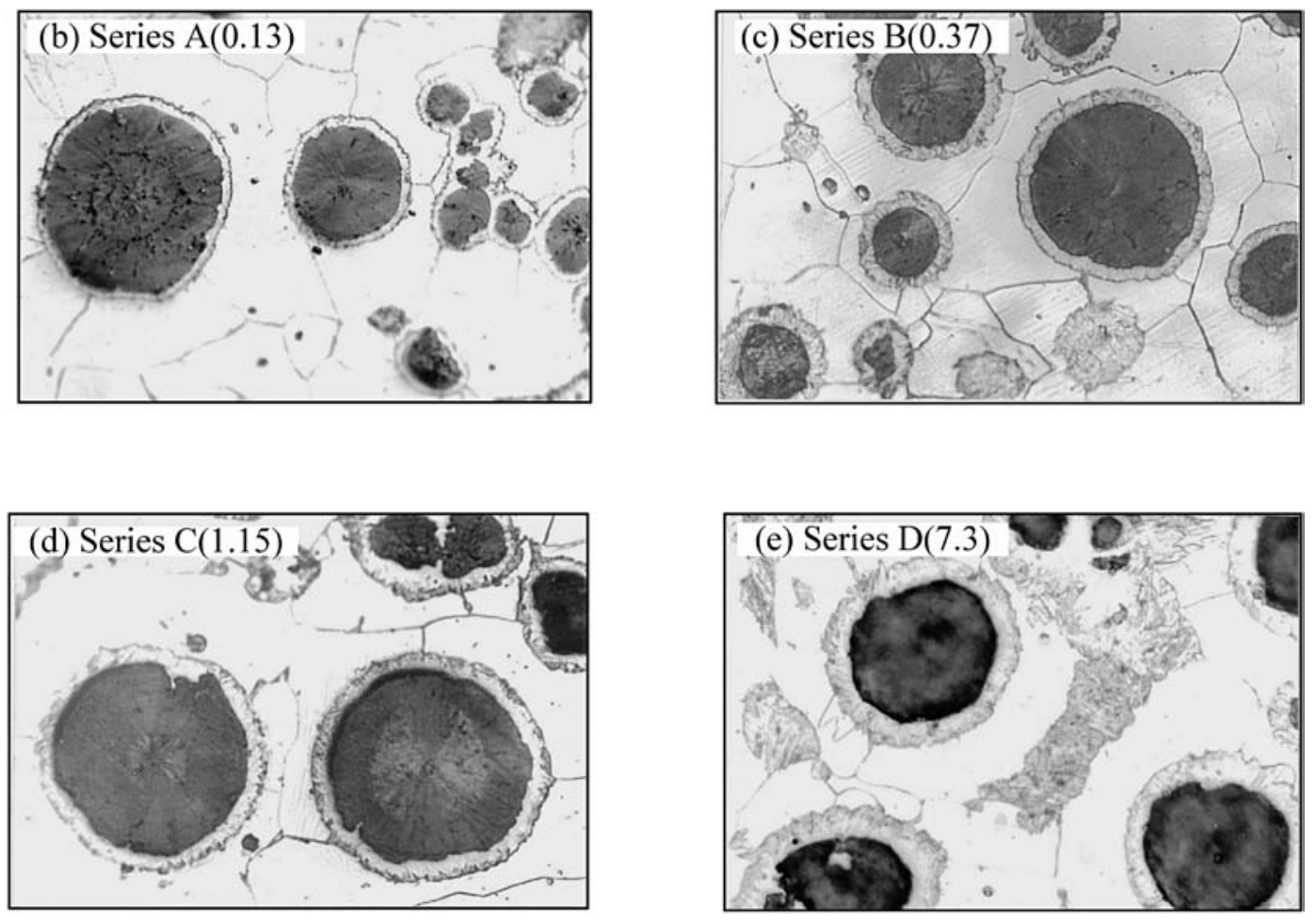

Fig. 3 Optical microstructures. 
装置を用いて試験片 $\mathrm{R}$ 部の軸方向の残留応力を測定した. 疲労試験は，試験片の最小径部をエメリ一紙とバフ研磨によ り鏡面仕上げした後，小野式回転曲げ疲れ試験機 $(50 \mathrm{~Hz})$ を 用いて行った。本研究では, $10^{7}$ 回の繰返し負荷で破断に至 らなかった最大応力を疲労強度とした．破断後の試験片につ いては破面のマクロ観察ならびに走査型電子顕微鏡 $(\mathrm{SEM})$ によるミクロ観察を行い, 破壊起点部を特定した。

\section{3. 実験結果および考察}

\subsection{SRIHQ した FDI の金属組織}

Fig. 3 に未処理材および $\mathrm{A} \sim \mathrm{D}$ シリーズの $\mathrm{R}$ 部表面近傍 の組織写真を示す. 未処理材はフェライト+球状黒鉛である のに対して, SRIHQ 材は黒鉛の周りに灰色層が観察され た．この灰色層は，Fig. 4 に示すように，加熱時間が長くな るのに伴い，厚くなっていることがわかった.

そこで，この灰色層組成を精査し，生成メカニズムを明ら かにするために，黒鉛周りの炭素分布を電子線マイクロアナ ライザー $(\mathrm{EPMA})$ を用いて測定（ビーム径 $1 \mu \mathrm{m})$ した。 その 結果，Fig. 5 に示すように炭素量は黒鉛の表面近くで最も多 く，黒鉛から離れると少なくなった。また，炭素の拡散部分 は灰色層の厚さとほぼ一致していた，次に，灰色層が非常に 薄いので，測定荷重 $9.8 \mathrm{mN}$ でマイクロビッカース硬さを測 定した結果，灰色層は 850 890 HV と高硬さであった。

以上の結果から，この灰色層は SRIHQ での加熱により黒 鉛中の炭素が分解し, フェライト中に固溶・拡散し, そし て，急速冷却により，拡散部分が変態してマルテンサイトが 形成されていると考えられる．このマルテンサイト層は，3 次元的には卵の殸状ではあるが，以下では，このマルテンサ イト層を「環状マルテンサイト層」と称す。

Fig. 6(b)-(e)に試験片最小径部における深さ方向の硬さ 分布を示す。破線は未処理材の硬さである (Fig. 6(a)). SRIHQ を施したFDI においては，溶製鋼のように明確な硬 化領域は表われないが，硬化層に扔いては未処理材に比べ， 100〜200 HV の硬さ増加が見られた。また，加熱時間が長

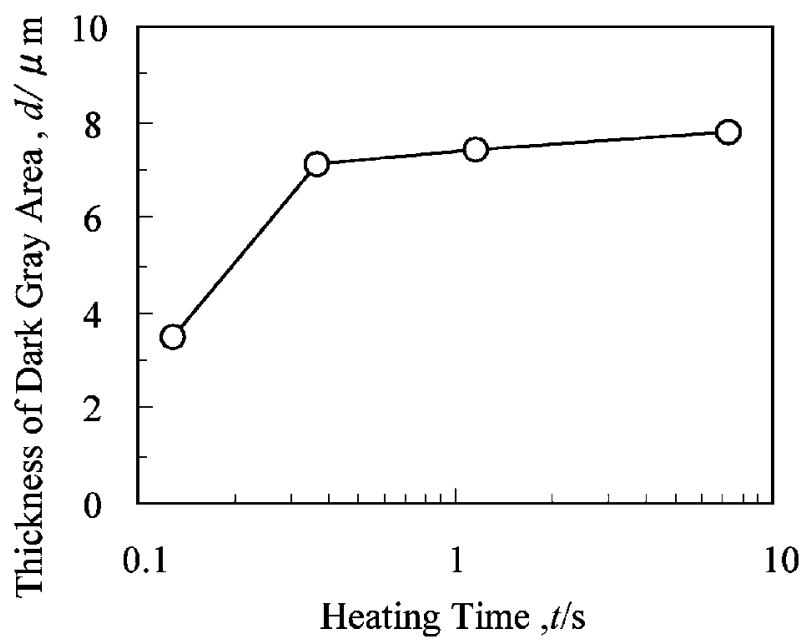

Fig. 4 Relation between heating time and thickness of dark gray area.
くなると, 硬化層はより深くなった，この硬化層の硬さ増加 は環状マルテンサイト層の生成によるものと考えられる.

Fig. 7 に試験片 $\mathrm{R}$ 部表面の軸方向の残留応力測定結果を 示す。既報4)では溶製鋼を用いた試験片に SRIHQ を施すこ とにより，-1000 MPa を超える高い圧縮残留応力が生起し ていた。しかし，今回の FDIにおいては，溶製鋼ほどの高 い圧縮残留応力は生起しなかった。

一般に高周波焼入れのような表面硬化の場合，急熱急冷に よりマルテンサイト変態し，膨張した表面が内部の非加熱部 分に引き込まれて弾性変形するために，表面には圧縮残留応 力が生成すると考えられる7)。しかしながら，SRIHQを施
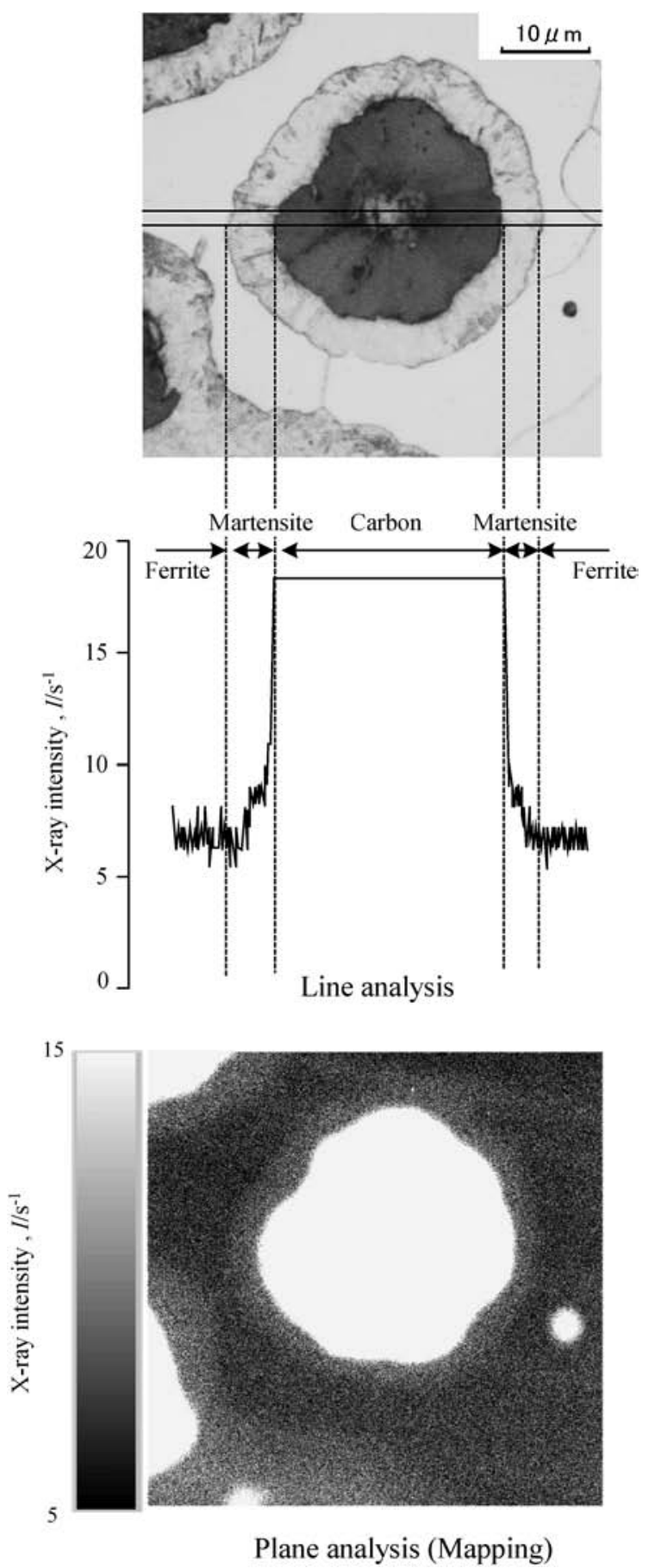

Fig. 5 Carbon distribution (Series B (0.37)). 

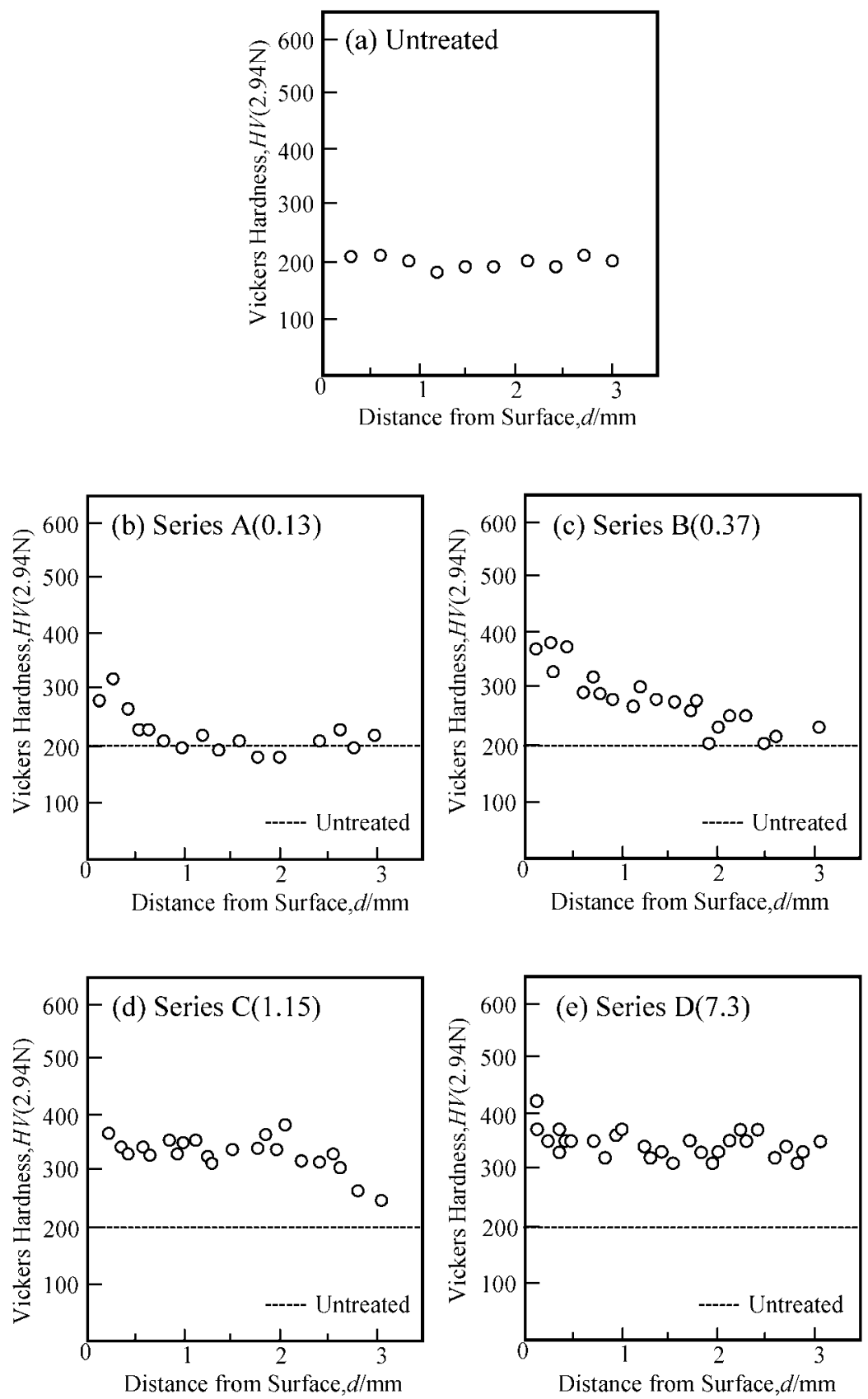

Fig. 6 Microhardness distributions.

した FDI においては，2 種類の残留応力生成機構が存在す ると考えられる.ひとつは前述したマク口的な生成機構とも うひとつは環状マルテンサイト層によるミクロ的な生成機構 である. Fig. 8 の上図は表面部が硬化，膨張することにより 表面部に圧縮残留応力場が生成するマクロ的機構で，下図は 環状マルテンサイト層が生成することにより，黒鉛周りに圧 縮残留応力場が生成するミクロ的機構を示す.

A シリーズで圧縮残留応力が低かったのは, 環状マルテ ンサイト層厚さが $\mathrm{B}, \mathrm{C}$ シリーズに比べて小さいため, ミク 口的な圧縮残留応力の効果が少なかったためと考元られる. 一方，Dシリーズで低かったのは，内部まで硬化されてい ることにより, マクロ的な圧縮残留応力の効果が少なかった ためと考えられる。

\subsection{FDI の疲労強度におよぼす SRIHQ の影響}

Fig. 9 に未処理材抢よび A〜D シリーズの疲労試験結果を 示す. SRIHQ を施すことにより, 疲労強度は, 未処理材に 比べて大きく向上していることがわかった． A〜Cシリーズ を比較すると，A シリーズに比べ，加熱時間が長い B, C シ リーズの疲労強度が向上することがわかった。これは, 加熱 時間が長くなるにつれ，前述したように，環状マルテンサイ 卜層が厚く形成され, また, 圧縮残留応力も高くなることに より, 疲労き裂の発生扔よび進展に対する抵抗がより大きく なったためと考えられる.なお， B, C シリーズがほぼ同等 の疲労強度を示したのは, Fig. 4, 7 に示すように両材の環 状マルテンサイト層厚さ, 圧縮残留応力がほぼ同等の值であ ったためと考えられる。一方，Dシリーズの疲労強度が $\mathrm{B}$, 


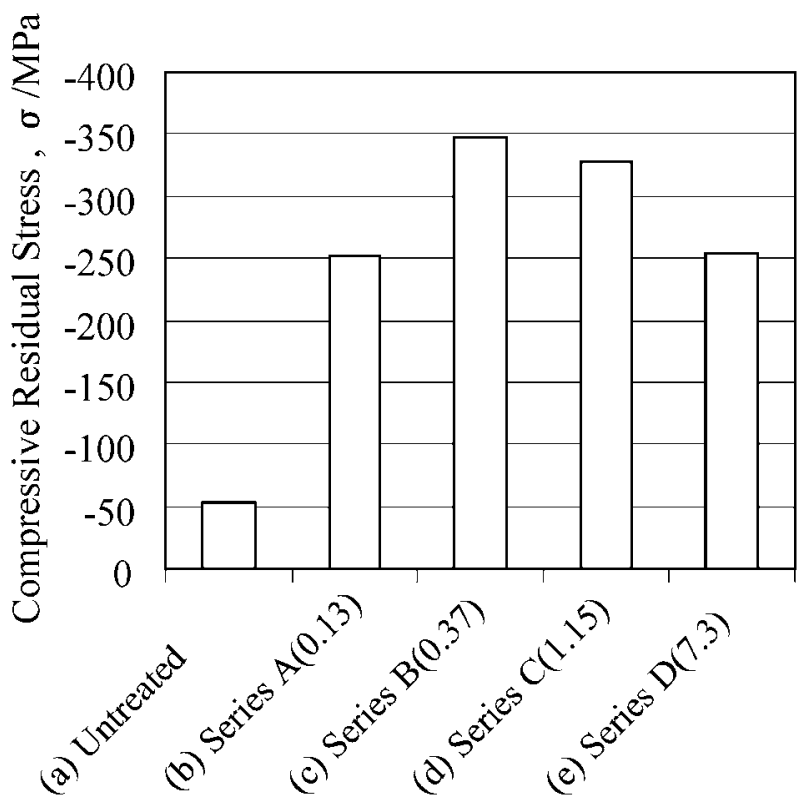

Fig. 7 Relation between heating time and residual stress.

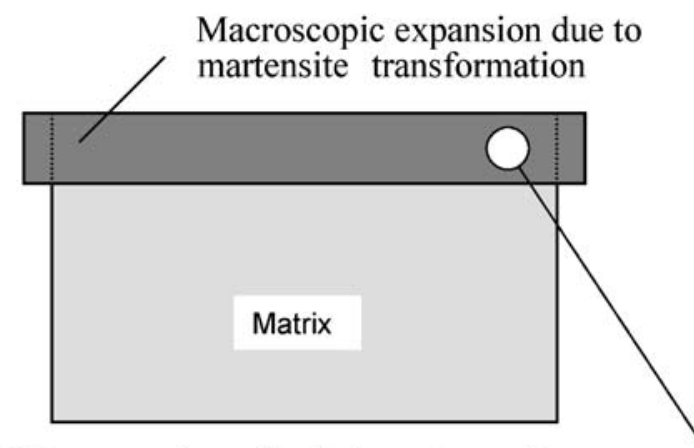

(a) Macroscopic residual stress generative process

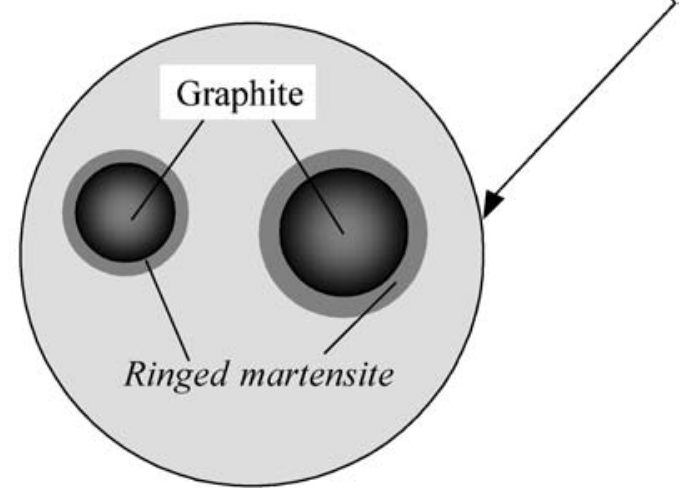

(b) Microscopic residual stress generative process

Fig. 8 Schematic illustration of the macroscopic and microscopic residual stress generative process.

Cシリーズに比べ若干低かったのは，硬化部の圧縮残留応力 が低かったためと考えられる.

次に，SRIHQにより形成された環状マルテンサイト層の 疲労破壊機構への影響を明らかにするために，疲労試験中の 疲労き裂の発生，進展挙動をビデオマイクロスコープにより 観察した.

その代表例として，Fig. 10 に未処理材打よび最も疲労強

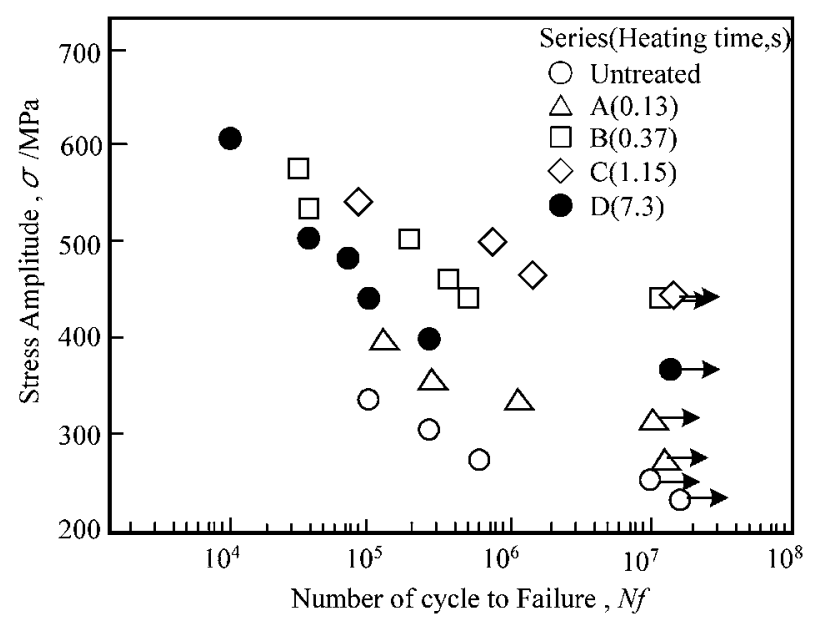

Fig. 9 Result of rotational bending fatigue tests.

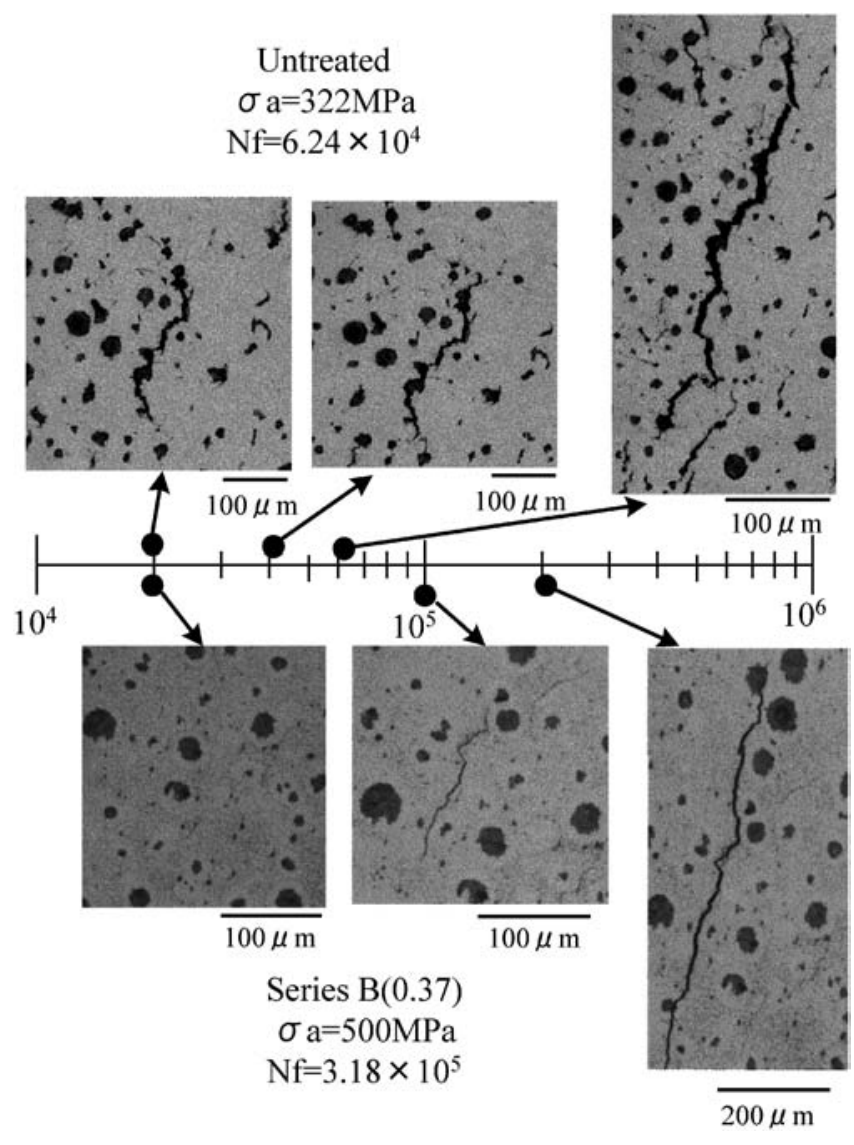

Fig. 10 Typical feature of crack propagation behavior.

度が高かった B シリーズの観察結果を示す．未処理材で は，き裂の起点部はほとんぞが黒鉛組織周辺で，発生したき 裂は黒鉛とフェライト地の境界を貫通するように進展してい るのに対し，Bシリーズの場合，疲労き裂の発生は黒鉛抢よ びフェライト組織からであるが，黒鉛周辺から発生したき裂 は未処理材に比べて少なく，Fig. 11 に示すようにき裂は環 状マルテンサイト層を迂回するように進展していることがわ かった。これは，フェライト基地組織から発生した主き裂の 進展が，環状マルテンサイト層の高硬さ㧍よびその生成によ る圧縮残留応力場によって，黒鉛への侵入を抑制されたため 


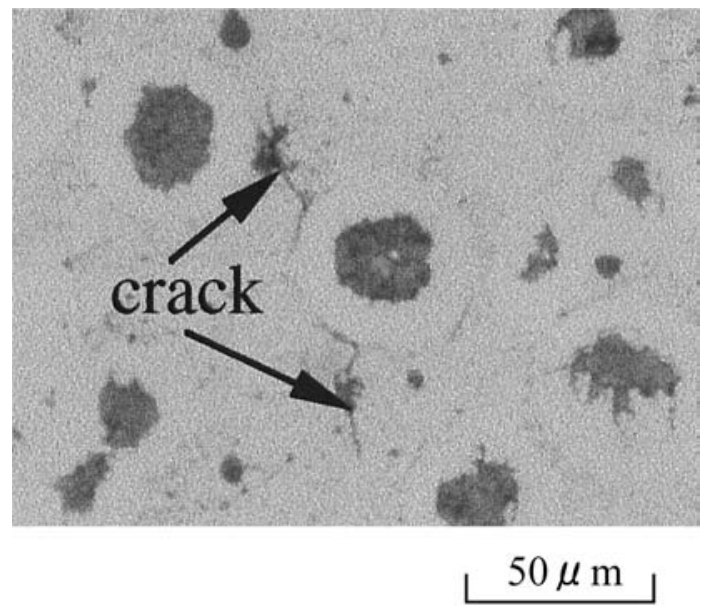

Fig. 11 Typical feature of crack propagation behavior (Series B $(0.37))$.

(a) Untreated

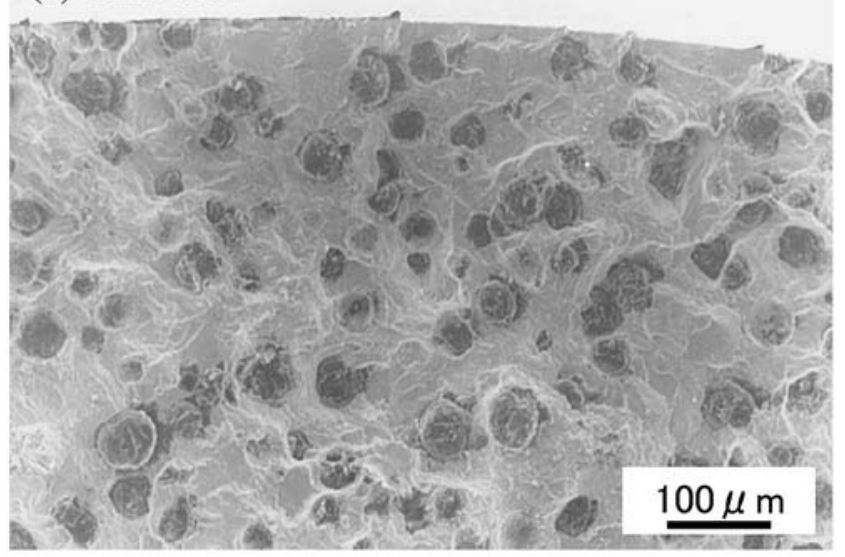

(b) Series B(0.37)

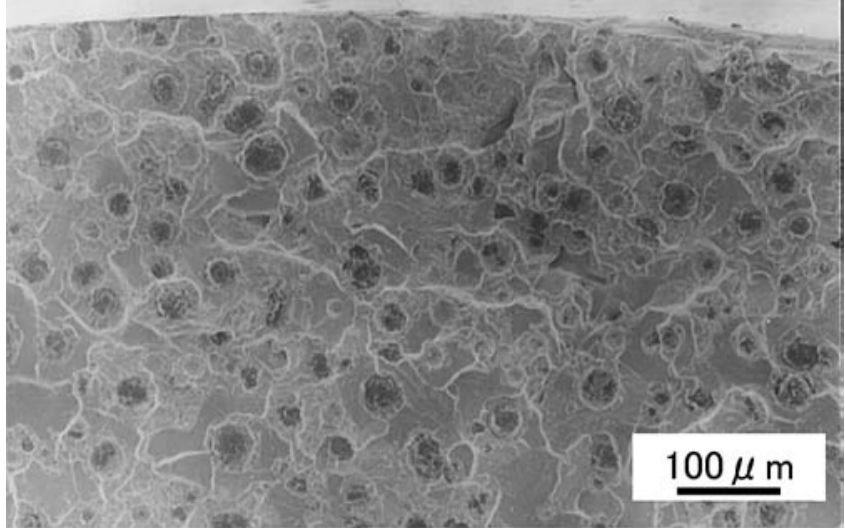

Fig. 12 SEM fractographs of the fracture surface.

\section{と考えられる.}

次に，SEMを用いて破面のミクロ観察を行った．Fig. 12 に末処理材と B シリーズの SEM 観察を行った。その結果， 破面中に見られる黒鉛の面積率が異なることがわかった。そ こで，黒鉛破面率(破面中に観察される黒鉛の面積率)を測定 したところ，Fig. 13 に示すように未処理材に比べ，SRIHQ 材の方が少ないことがわかった。このことは，未処理材にお

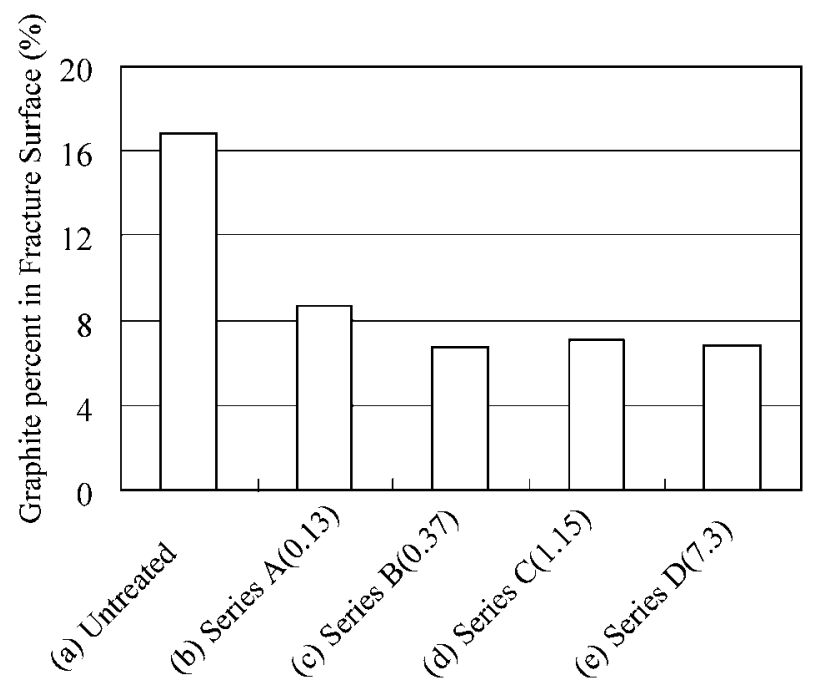

Fig. 13 Graphite percent in fracture surface.

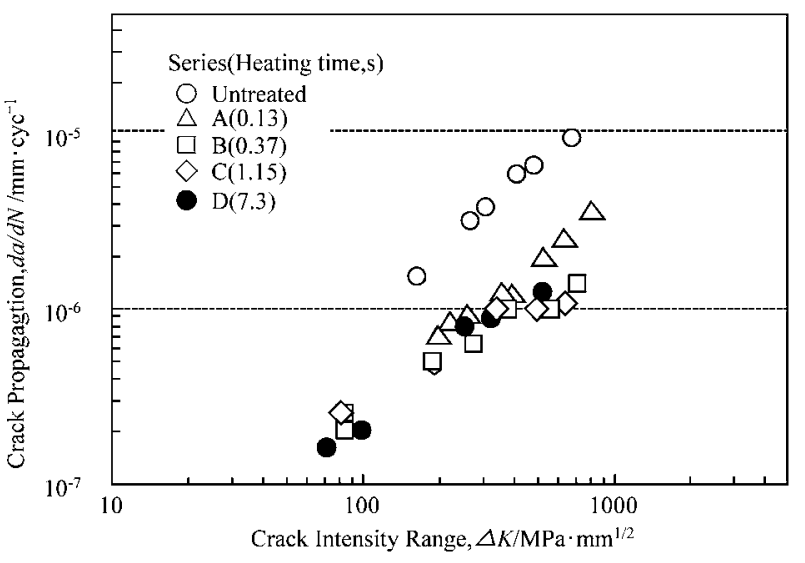

Fig. 14 Relation between crack propagation rate and $\Delta K$.

いてはき裂が黒鉛を通過して破壊している率が高いことを示 唆しており，今まで述べてきた現象を裏付けている。

以上の結果, SRIHQ を施すことにより, 環状マルテンサ イト層の生成およびそれに伴う圧縮残留応力場生起の効果に より，き裂の発生および進展が抑制されたものと考えられる.

また，疲労き裂の発生および進展機構を定量的に評価する ために疲労限の 1.1 倍の荷重で試験を行い, 表面き裂の進展 状況を, 応力拡大係数幅を求めることにより評価した. Fig. 14 にき裂進展速度と $\Delta K$ の関係を示す．未処理材のき裂進 展速度は, SRIHQ 材より高く, 傾きも, 未処理材では, SRIHQ 材より大きかった.

以上のことより， SRIHQ は FDI のき裂進展を抑制する効 果があると考えられる.

\section{4. 結言}

フェライト地の球状黒鉛鋳鉄 $(\mathrm{FDI})$ の疲労強度特性におよ ぼす超急速短時間加熱焼入れ (SRIHQ)の効果を明らかにす るために，4 種類の熱処理サイクルを施した試験片の回転曲 げ疲労強度を評価した。その結果, 以下のことが明らかにな った。 
（1）SRIHQ を施すことにより，黒鉛周りには灰色の薄い マルテンサイト層が生成する(環状マルテンサイト層).

（2）環状マルテンサイト層により表面硬化層には圧縮残留 応力場が生起し, この圧縮残留応力の生成機構には 2 つの タイプがあり，1つは環状マルテンサイト層生成に伴うミク 口的残留応力と，もうひとつは表面部の焼入硬化による膨張 に伴うマクロ的残留応力である.

(3) FDI VRIHQ を施すことにより，未処理材に比べ疲 労強度は向上する．これは環状マルテンサイト層が生成する ことにより発生する圧縮残留応力場が，き裂の発生，進展を 抑制するためと考えられる。

本実験を行うにあたり，試料の提供およびご助言をいただ
いた日立金属侏 石澤俊崇様に感謝いたします。

文献

1) Bartosiewicz L, Krause, Kovacs $B$ and Putatunda $S$ K: Trans. Am. Foundrymen Soc. 100(1992) 135-142.

2) Heuler P, Hueck M and Walter H: Konstr Giess 17 (1992) 15-27.

3) J. Storm and M. Chaplin: Heat Treat. 19(1987) 30.

4) Y. Misaka, Y. Kiyosawa, K. Kawasaki and T. Yamazaki: SAE Technical Paper Series 97971(1997) 121-130.

5) Y. Misaka, Y. Kiyosawa, K. Kawasaki and T. Yamazaki: The 2nd Asian conference on Heat Treatment of Material (2001) pp. 50-55.

6) J. Komotori, M. Shimizu, Y. Misaka and K. Kawasaki: International Journal of Fatigue 23(2001) S255-S230.

7) George E. Totten and Maurice A. H. Howes: Steel Heat Treatment, (Marcel Dekker, Inc.) (1997) pp. 835-836. 